\title{
EXPERIMENTAL MEASUREMENTS OF A CARBON DIOXIDE CONCENTRATION FOR DETERMINING OF A VENTILATION INTENSITY IN A ROOM AT PULSING MODE
}

\begin{abstract}
Air distribution by interaction of counter non coaxial air jets at pulsing mode has been considered. Dynamic parameters of air flow that is created due to interaction of counter non coaxial flat air jets at their leakage at pulsing mode and creation of dynamic indoor climate in a room has been determined. This paper is aimed to develop a methodology for determining the intensity of ventilation of indoor premises based on the experimental measurements of the concentration of carbon dioxide. Using experimental measurements and the knowledge gained in the study of this issue, in the work the method for intensity ventilation determining of the indoor premises was developed on the basis of the measured values of carbon dioxide which was verified also by another experimental measurements. The resulting values of ventilation intensity rate obtained by calculation from the measured values of carbon dioxide were compared with the results of calculations executed according to the laws and standards, valid in Slovakia. Based on measured values of carbon dioxide concentrations a method for calculation of the ventilation intensity was developed and compared with the methods used in Slovakia.
\end{abstract}

Keywords: air distribution, air jet, pulsing mode, dynamic indoor climate, air velocity, flow rate

\section{Introduction}

Considering the fact that in operating costs of the new building the important place take expenses on heating, mainly, on air heating in systems of ventila-

\footnotetext{
${ }^{1}$ Author for correspondence: Peter Kapalo, Department of Engineering Equipment of Buildings, Kosice Technical University, Vysokoškolská 4, 04001 Košice, Slovakia, tel: 055/602 4211, peter.kapalo@tuke.sk.

2 Orest Voznyak, "Heat, Gas Supply and Ventilation" National University "Lviv Polytechnic", Bandery Str.12, Lviv, Ukraine, 79013, tel: +380 322 582784, orest.voznyak@i.ua
} 
tion, the measures directed on optimization of the intensity of ventilation at maintaining comfort of consumers, are of high importance and have national character.

To reduce electricity consumption it is possible to use air-conditioning equipment providing heat recovery from exhaust air. When choosing the ventilating equipment it is necessary to consider the correct boundary conditions that the ventilating equipment wasn't the overestimated or underestimated power with the aim of optimizing investment and operating costs of ventilation equipment in compliance with sanitary requirements with regard to air quality in the internal environment of buildings.

Investigations in non-industrial and industrial buildings testify that exactly variable irritants influence favourably on human's thermal sensitivity. Pulsing mode of flowing out incoming jets means the creation of dynamic indoor climate that positively reflects on the thermal regulation of human's organism.

\section{State of problem}

Analysis for calculating the intensity of ventilation rate in the buildings is carried out according to regulations and standards valid in Slovakia. In Slovakia the estimated ventilation intensity is regulated by several law regulations and instructions:

- Edict of the government of the Slovak Republic 391/2006 from 24 of May 2006 [1].

- Edict of the Ministry of transport, construction and region development of the Slovak Republic 364/2012 from 12 of November 2012 [2].

- Standard STN 73 0540-2 Thermal protection of buildings. Thermotechnical properties of building constructions and structures. Part 2: Functional requirements. July 2012 [3].

- Standard STN EN 15251: 2007 Indoor environmental input parameters for design and assessment of energy performance of buildings addressing indoor air quality, thermal environment, lighting and acoustics [4].

- Standard STN EN 13779 Ventilation for non-residential buildings. General requirements for ventilation and air-conditioning equipment. April 2005 [5].

Intensity of air exchange in the tested room generally can be defined by calculations and measurements. In this work the room with natural ventilation is examined. In the most part of the room there is an uncontrollable air infiltration and exfiltration. Natural ventilation can be considered as air exchange of the internal environment due to the pressure difference, which is caused by the effects of natural forces arising from temperature difference or the dynamic action of wind.

This problem is complicated by taking into account the ventilation pulsing mode and creating of dynamic indoor climate in the room. The dynamic indoor 
climate provides more comfortable conditions for human body both heat and dynamic aspects.

We can give an example of the well-known research of working place ventilation system for welding shops with the pulse air flow and frequency of its oscillation in a serviced area $n=6-15 \mathrm{~min}^{-1}$ and period $\mathrm{T}=4-10 \mathrm{sec}$. Also the appliance is known that is an air pipe divided by a lengthwise partition. Its installation gives an opportunity to ensure a periodical change of velocity of exit air jet from the nozzle at the expense quantity change of incoming air in each of two parts of this air pipe.

The aim of this work is the determination of $\mathrm{CO}_{2}$ concentration at air flow, that is created by interaction of counter non coaxial flat jets at their leakage at pulsing mode and creation of dynamic indoor climate in a room.

The increasing of the $\mathrm{CO}_{2}$ concentration can be mathematically represented by the following formula:

$$
C_{I D A}=C_{S U P}+\frac{q_{m}}{q_{v}} \cdot\left(1-\exp \left(\frac{-q_{v}}{V_{M}} \cdot t\right)\right) \quad\left[\mathrm{mg} / \mathrm{m}^{3}\right]
$$

where: $\mathrm{C}_{\mathrm{IDA}}$ - concentration of $\mathrm{CO}_{2}$ in the air in a room for time $\mathrm{t}\left[\mathrm{mg} / \mathrm{m}^{3}\right]$;

$\mathrm{C}_{\text {SUP }}$ - concentration of $\mathrm{CO}_{2}$ in the supply air for time $\mathrm{t}\left[\mathrm{mg} / \mathrm{m}^{3}\right]$;

$\mathrm{q}_{\mathrm{m}}$ - mass flow rate of $\mathrm{CO}_{2}$ in the room, which comes from the source of pollutants $[\mathrm{mg} / \mathrm{s}]$;

$\mathrm{q}_{\mathrm{V}}$ - the volume of airflow required for the ventilation of the room $\left[\mathrm{m}^{3} / \mathrm{s}\right]$ at constant regime;

$\mathrm{V}_{\mathrm{M}}$ - volume of the room $\left[\mathrm{m}^{3}\right]$;

$\mathrm{t}$ - time [s].

Mentioned values indicate the volume of the room, time of change $\mathrm{CO}_{2}$ concentration, given in $\mathrm{ppm}$, to be recalculated in units of $\mathrm{mg} / \mathrm{m}^{3}$. Unknown quantities are our mass flow of pollutants and flow rate of fresh air that penetrates into the room due to infiltration.

The value of ventilation rate is determined similarly by the graph on the basis of changes in the concentration of $\mathrm{CO}_{2}$. When calculating changes in $\mathrm{CO}_{2}$ concentration formula 1 is used, in which we take a mass flow of $\mathrm{CO}_{2}$, the volume of the room and measured initial concentration of $\mathrm{CO}_{2}$. The calculations are performed for each hour and for different intensity of ventilation. The overall result should be arranged in such way that the initial value of $\mathrm{CO}_{2}$ concentration was specified in ppm. For our case, results are shown in figure 1. In figure 1 we can see the increasing of the concentration of $\mathrm{CO}_{2}$ at different intensity of ventilation. The curve which is second in order from the top marks the course of $\mathrm{CO}_{2}$ concentration for ventilation rate $\mathrm{n}=0.5 \mathrm{1} / \mathrm{h}$, which corre- 
sponds to the obtained ventilation intensity due to infiltration in the office. Calculated changes of $\mathrm{CO}_{2}$ concentration correspond to the actual measured value.

The concentration of $\mathrm{CO}_{2}$ in outdoor air in our case amounted to $380 \mathrm{ppm}$. The initial concentration of $\mathrm{CO}_{2}$ in the beginning of measurements was $380 \mathrm{ppm}$. If the desired level of $\mathrm{CO}_{2}$ will be $1000 \mathrm{ppm}$, then in figure 1 we are looking for the value of the concentration of $\mathrm{CO} 2$, which does not exceed the limit value of $1000 \mathrm{ppm}$. The required intensity of ventilation is determined graphically on the basis of changes in the concentration of $\mathrm{CO}_{2}$, described in figure 1 . In our case, changes in the concentration are described by the solid line indicating the intensity of ventilation $0.7 \mathrm{l} / \mathrm{h}$.

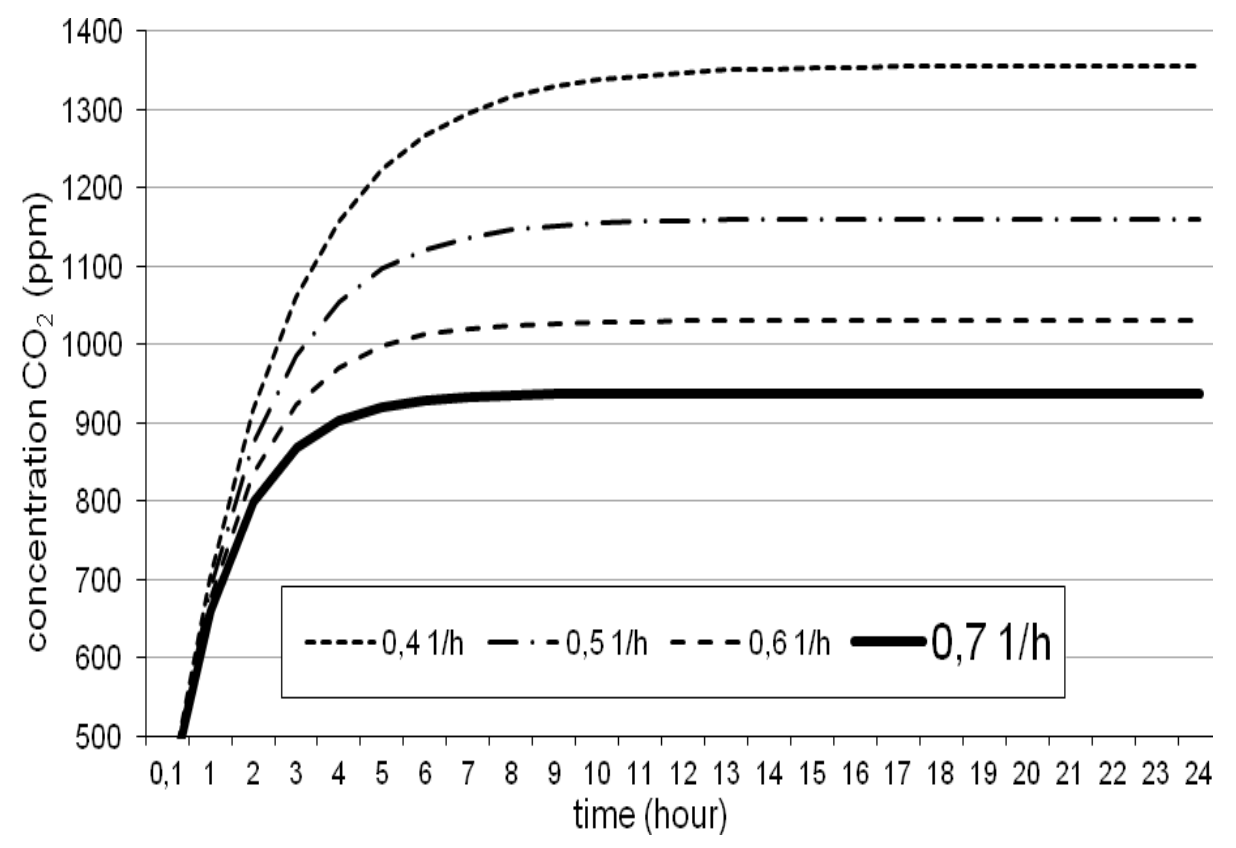

Fig. 1. Changes in the concentration of $\mathrm{CO}_{2}$ at different intensity of ventilation - work in a sitting position

Rys. 1. Zmiany stężenia $\mathrm{CO}_{2}$ przy różnym nasileniu wentylacji - praca w postawie siedzącej

This is constant regime and now let us consider the scheme of interaction of counter non coaxial air flat jets at their leakage at pulsing mode (figure 2), where air flow and initial velocity change in accordance with periodic regularity.

Let the jet is symmetrical relatively its axis, and the axial velocity $\mathrm{V}_{\mathrm{x}}$ in determined point $\mathbf{A}$ with coordinate $\mathbf{X}_{\mathbf{A}}$ in case of constant motion (without using pulse mode) determines from the formula of calculation of the axial velocity $\mathbf{V}_{\mathbf{o}}$ is known. 
a)

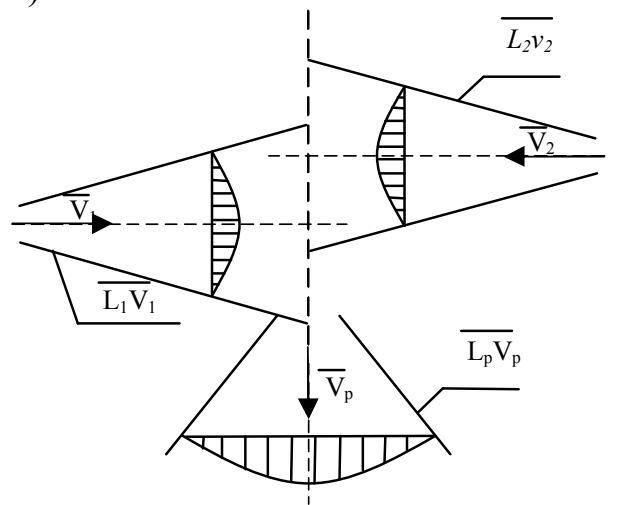

c) b)

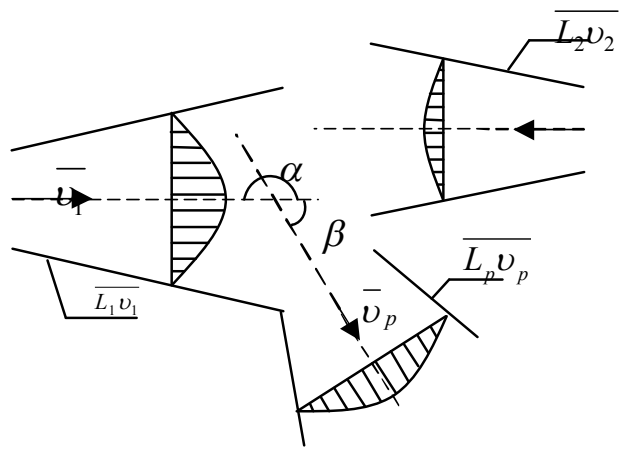

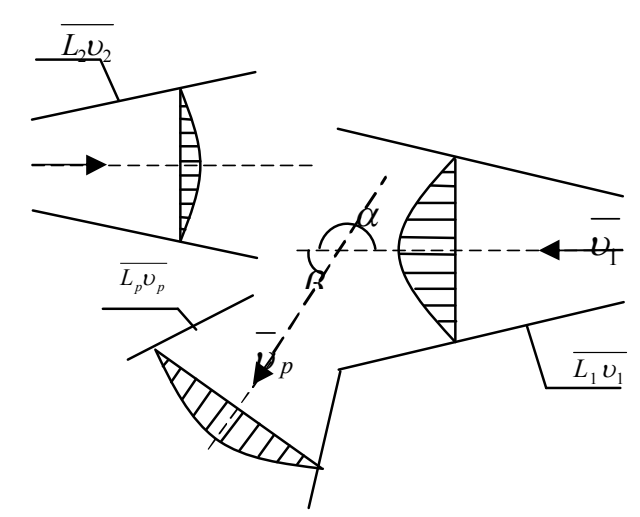

Fig. 2. Scheme of interaction of counter non coaxial flat air jets: a) $\mathrm{L}_{1}=\mathrm{L}_{2} ;$ b) $\mathrm{L}_{1}>\mathrm{L}_{2} ;$ c) $\mathrm{L}_{1}<\mathrm{L}_{2}$ Rys. 2. Schemat interakcji w łączniku z nieosiowymi płaskimi dyszami powietrza: a) $\mathrm{L}_{1}=\mathrm{L}_{2}$; b) $\left.\mathrm{L}_{1}>\mathrm{L}_{2} ; \mathrm{c}\right) \mathrm{L}_{1}<\mathrm{L}_{2}$

Using the pulse supply with a help of appliance [2] initial velocity $\mathrm{V}_{0}$ of jet exit from the nozzle will oscillate according to the periodical order, namely it will change within the limits from $\mathrm{V}_{0 \min }$ to $\mathrm{V}_{0 \max }$

$$
V_{0}=\bar{V}_{0}+A \cdot \cos \omega t
$$

where $\overline{V_{0}}$ - mean $V_{0}$ at period of vibration, $\mathrm{m} / \mathrm{s}$;

A - amplitude of $\mathrm{V}_{0}$ oscillation, $\mathrm{m} / \mathrm{s}$;

$\omega$ - cyclic frequency of oscillation, $\mathrm{s}^{-1}$;

t- time, $s$. 
Values $\overline{V_{0}}$, A and $\omega$ can be determined from the formulas:

$$
\begin{aligned}
& \bar{V}_{0}=0,5 \cdot\left(V_{O_{\max }}+V_{O_{\min }}\right) \\
& A=0,5 \cdot\left(V_{0_{\max }}-V_{0_{\min }}\right) \\
& \omega=\frac{2 \pi}{T}
\end{aligned}
$$

$\mathrm{T}$ - period of oscillation, [s].

We observe that during the initial moment of time the neutral position of partition was taken.

Similarly lets write the expression for the axial velocity oscillation when $\omega=\frac{2 \pi}{T}$ is taken into consideration.

$$
V_{x}=\bar{V}_{x}+B \cdot \cos \left(\frac{2 \pi}{T} t-\varphi\right)
$$

Since axial velocity $\mathrm{V}_{\mathrm{x}}$ is late at phase comparatively with $\mathrm{V}_{0}$, so initial phase comes into expression with negative sign.

Mean $\mathrm{V}_{\mathrm{x}}$ and amplitude of its regression $\mathrm{B}$ are determined analogically as the initial parameters:

$$
\begin{gathered}
\bar{V}_{x}=0,5 \cdot\left(V_{x_{\max }}+V_{x_{\min }}\right) \\
B=0,5 \cdot\left(V_{x_{\max }}-V_{x_{\min }}\right)
\end{gathered}
$$

After that we obtain:

$$
\bar{V}_{x}+B \cdot \cos (\omega t-\varphi)=\bar{V}_{0} \frac{m \sqrt{F_{0}}}{x}+A \frac{m \sqrt{F_{0}}}{x} \cdot \cos \omega t
$$

From constant mode is the partial case of the pulse supply with the amplitudes of oscillation $\mathrm{A}=0$ and $\mathrm{B}=0$, so equation (9) changes into (10) and is analogical to (1).

$$
\bar{V}_{x}=\bar{V}_{0} \frac{m \sqrt{F_{0}}}{x}
$$


Taking into consideration (9), (10) we have:

$$
B \cdot \cos \left(2 \pi \frac{t}{T}-\varphi\right)=A \frac{m \sqrt{F_{0}}}{x} \cdot \cos 2 \pi \frac{t}{T}
$$

from where we determine amplitude B:

$$
B=A \frac{m \sqrt{F_{0}}}{x} \cdot \frac{\cos 2 \pi t / T}{\cos (2 \pi t / T-\varphi)}
$$

Air flow rate in pulsing mode (figure 3):

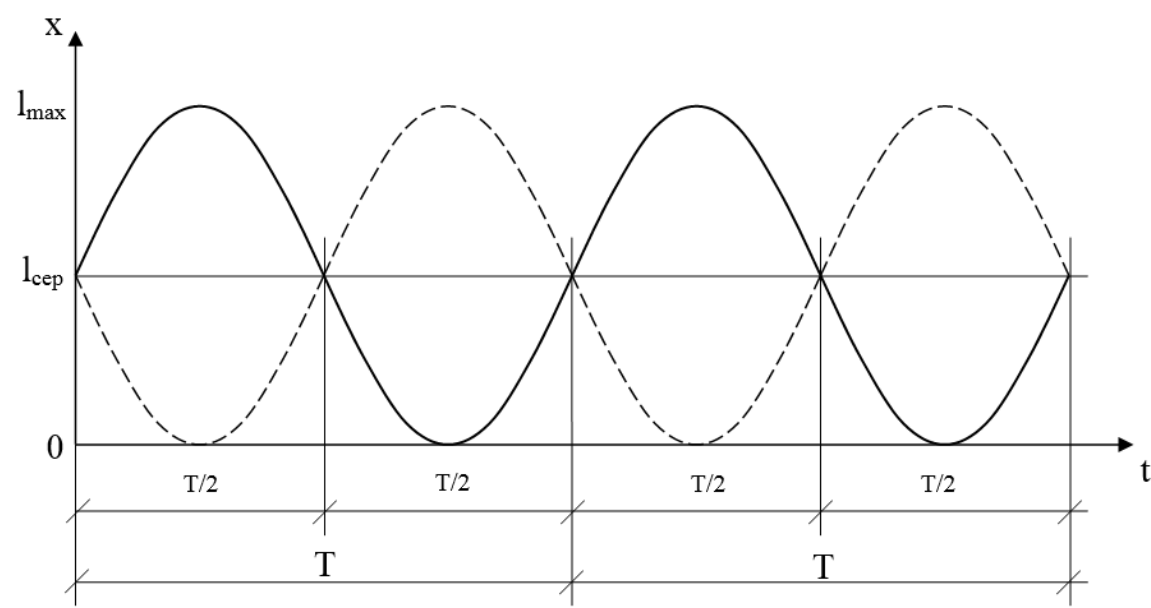

Fig. 3. Periodical change both of air flow rate and $\mathrm{CO}_{2}$ concentration in the room

Rys. 3. Cykliczna zmiana zarówno wskaźnika przepływu powietrza jak i stężenia $\mathrm{CO}_{2}$ w pomieszczeniu

$q_{0}=\bar{q}+A_{1} \sin \omega t$

Concentration of $\mathrm{CO}_{2}$ in the supply air for time $\mathrm{t}\left[\mathrm{mg} / \mathrm{m}^{3}\right]$ in pulsing mode:

$C_{S U P}=\bar{C}+A_{2} \sin \omega t$

Concentration of $\mathrm{CO}_{2}$ in the air in a room for time $\mathrm{t}\left[\mathrm{mg} / \mathrm{m}^{3}\right]$ in pulsing mode:

$$
C_{I D A}=\bar{C}+A_{2} \sin \omega t+\frac{q_{m s}}{\bar{q}+A_{1} \sin \omega t}\left(1-\exp \frac{\bar{q}+A_{1} \sin \omega t}{V_{M}}\right)
$$




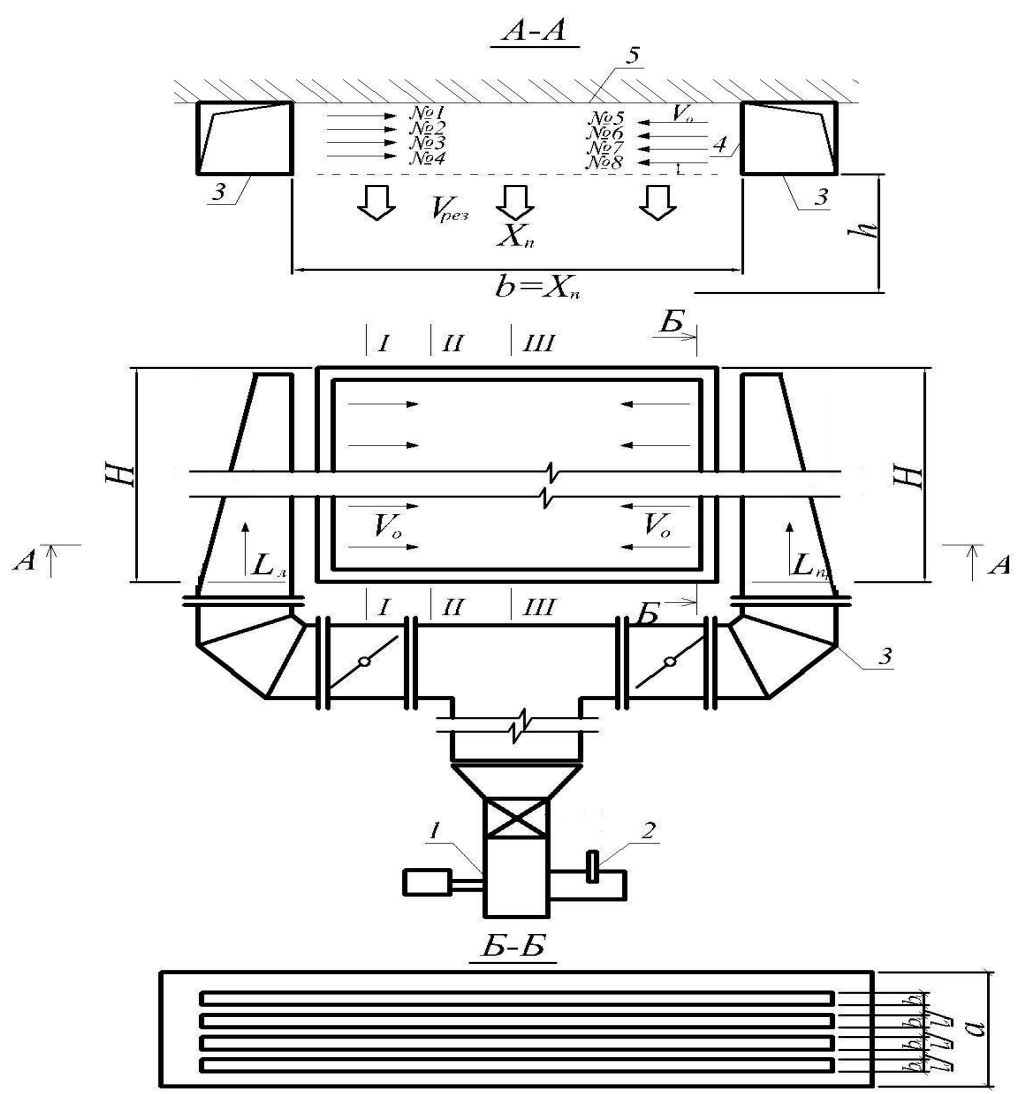

Fig. 4. Scheme of experimental installation, where: 1 - radial fan; 2 -damper; 3 - air pipe with size $a \times b=350 \times 350 \mathrm{~mm} ; 4$-air distribution devices with width by $b_{\mathrm{o}}=20 \mathrm{~mm} ; 5$ - base; $h$ - running distance

Rys. 4. Schemat eksperymentalnej instalacji, gdzie: 1 - wentylator promieniowy; 2 - zasuwa; 3 - przewód wentylacyjny o przekroju a x $\mathrm{b}=350 \times 350 \mathrm{~mm} ; 4$ - mechanizm rozdziału powietrza o szerokości $b_{o}=20 \mathrm{~mm} ; 5$ - podstawa; $h$-droga przepływu

Experimental investigations have been carried out at the installation, presented on figure 4 at such conditions and simplifications:

- air jets are isothermal;

- incoming nozzles are holes with width $20 \mathrm{~mm}$ and with length of $1,5 \mathrm{~m}$;

- coefficient of velocity extinction $\mathrm{m}=2,5$;

- initial air velocities in nozzle were: $\mathrm{v}=5-15 \mathrm{~m} / \mathrm{s}$;

- period of velocity change at experimental investigations was constant: $\mathrm{T}=15 \mathrm{~min}$;

- air flow rates were: $\mathrm{L}=200-500 \mathrm{~m}^{3} / \mathrm{h}$.

Air velocity have been measured by thermal electrical anemometr testo405 at using coordinate device with net of points $5 \times 5 \mathrm{sm}$. 


\section{Conclusions}

1. Air flow rate in total flow is constant, but components $\mathrm{q}_{\mathrm{i}}$ are variable at periodic regularity. So does $\mathrm{CO}_{2}$ concentration.

2. Direction change of total air flow from 0 to $180^{\circ}$ is provided.

3.Pulsing mode of air distribution provides decreasing of $\mathrm{CO}_{2}$ concentration in a room.

\section{Acknowledgements} $4 / 2013$.

This article was elaborated in the framework of the project KEGA 052 TUKE-

\section{Bibliography}

[1] Kapalo P.: Analysis of ventilation rate and concentrations of carbon dioxide in the office Lviv. Visnik National University Lviv Polytechnic, Ukraine. September 2013. P. 69, ISSN 0321-0499

[2] Muntea C., Florin D., Kapalo P., Nagy R., Air quality and effect of ventilation in buildings. Visnyk Nats. Un-tu «Lvivska politehnika» № 737 «Teoria I praktyka budivnytstva», 2013. - c.78-82.

[3] Regulation of Ministry of Transport, Construction and Regional development of the Slovak Republic 364/2012 from 12 of November 2012.

[4] Edict 391/2006 Collection of Laws (2006) Enactment of ministry Slovak republic from 24. may 2006.

[5]Standard STN 73 0540-2 Thermal protection of buildings. Thermotechnical properties of building constructions and structures. Part 2: Functional requirements. July 2012.

[6] STN EN 15251 (2007) Indoor environmental input parameters for design and assessment of energy performance of buildings addressing indoor air quality, thermal environment, lighting and acoustics.

[7] Standard STN EN 13779 Ventilation for non-residential buildings. General requirements for ventilation and air - conditioning equipment. April 2005.

[8] Voznyak O.. Relationship between a Person Heat Exchange and Indoor Climate. "Selected scientific Papers" 10th Rzeszow-Lviv-Kosice Conference 2005 Supplementary Issue. Technical University of Kosice. - p. $148-152$.

[9] Voznyak O.. Dynamichnyj mikroklimat ta energooshchadnist - Visnyk Nats. Un-tu «Lvivska politehnika» № 460 «Teploenergetyka. Inzhenerija dovkillia. Avtomatyzatsija», 2002 (in Ukrainian) - c.150 - 153.

[10] Voznyak O., Myroniuk K., Sukholova I.. Zastosuvannya povitrorozpodilu vzayevodiyeyu zustrichnyh nespivvisnyh strumyn - Zbirnyk MOTROL «Motoryzacja I Energetyka rolnictwa», Tom 13 C, - Lublin, 2011 (in Ukrainian) - c.24 - 31. 


\section{POMIARY DOŚWIADCZALNE STĘ̇̇ENIA DWUTLENKU WĘGLA DLA USTALANIA INTENSYWNOŚCI WENTYLACJI W POKOJU W TRYBIE PULSACYJNYM}

\section{Streszcze n e}

$\mathrm{W}$ artykule rozpatrywano rozprowadzanie powietrza z uwzględnieniem interakcji w łącznikach z niewspółosiowymi dyszami powietrznymi w trybie pulsacyjnym. Określono dynamiczne parametry przepływu powietrza wywołane interakcją w łącznikach z niewspółosiowymi płaskimi dyszami powietrznymi na ich wylocie w trybie pulsującym i tworzonego dynamicznego klimatu wewnątrz pokoju. Zamierzeniem artykułu było opracowanie metodologii dla ustalania intensywności wentylacji wnętrza pokoju, bazując na pomiarach doświadczalnych stężenia dwutlenku węgla. Wykorzystując pomiary doświadczalne i wiedzę zdobytą w badaniach tego zagadnienia, w pracy nad określeniem metody dla intensywności wentylacji wewnątrz pokoju, jako podstawa zostały wykorzystane zmierzone wartości dwutlenku węgla, które były weryfikowane również przez inne pomiary doświadczalne. Wynikowe wartości wielkości intensywności wentylacji uzyskanej z obliczeń mierzonych wartości dwutlenku węgla zostały porównane z wynikami obliczeń wykonanych zgodnie z normalizacją i aktami prawnymi obowiązującymi na Słowacji. Na podstawie zmierzonych wartości stężenia dwutlenku węgla została opracowana metoda obliczania intensywności wentylacji i porównano ją z metodami wykorzystanymi na Słowacji.

Słowa kluczowe: rozdział powietrza, dysza powietrzna, tryb pulsacyjna, dynamika klimatu wewnętrznego, szybkość przepływu powietrza, natężenie przepływu

Przesłano do redakcji:8.06.2015

Przyjęto do druku:10.01.2016

DOI: $10.7862 / \mathrm{rb} .2015 .189$ 